\title{
Response of Muhlenbergia porteri Scribn. to Season of Defoliation
}

\author{
RICHARD F. MILLER AND GARY B. DONART
}

\begin{abstract}
Removing $65 \%$ of the leaf area of bush muhly in three consecutive years during the growing season reduced plant vigor regardless of season of clipping. Late or continuous season defoliation had the greatest impact on food reserves, production, crown diameter and number of stem internodes. Defoliation during the vegetative stage had the least effect of the clipping treatments.
\end{abstract}

Bush muhly (Muhlenbergia porteri) is a perennial grass characterized by numerous wiry, much-branched culms, growing on dry mesas and rocky slopes throughout the Southwest (Gould 1951). Historically forming extensive stands in parts of its range, bush muhly now is generally restricted to growing under the protection of shrubs and sub-shrubs. This grass species has been reported as being highly palatable (Gardner 1951). However, Welsh and Beck (1976) observed that the palatability of the species was only average and that it was sensitive to grazing because of its branching and nodal disarticulation characteristics.

Bush muhly can become established in badly deteriorated sites occupied primarily by crcosotebush (Larrea tridentata) where their geographic ranges overlap. As bush muhly gains in stature, it can outcompete creosotebush, leading to a decrease in shrub vigor and, in numerous instances, mortality (Welsh and Beck 1976). The ability of bush muhly to revegetate these areas naturally makes it a highly desirable plant to maintain or increase in abundance. We need more information on the growth characteristics of this species

Authors are assistant professor, Rangeland Resources Program, Oregon State University, Corvallis; and professor, Department of Animal and Range Sciences, New Mexico State University, Las Cruces, respectively. Miller was formerly graduate research assistant, Department of Animal and Range Sciences, New Mexico State University, Las Cruces.

This was submitted as Journal Article 747, New Mexico Agricultural Experiment Station, Las Cruces, New Mexico, 88003. It reports on work supported in part by Bureau of Land Management Contract YA-512-CT6-205.

Manuscript received November 11, 1979. if effective management is to be implemented.

The purpose of this study was to evaluate the effect of season of defoliation on (1) total nonst ructural carbohydrates, (2) number of elongated internodes, (3) production and (4) crown diameter.

\section{Study Area}

The study area was located on the New Mexico State University College Ranch, $32 \mathrm{~km}$ north of Las Cruces in Dona Ana County, New Mexico. The arid climate is characterized by low precipitation, low humidity, high temperatures, high evaporation potential, and periodic strong winds. Average annual rainfall is $22 \mathrm{~cm}$. Approximately $55 \%$ of the annual precipitation falls during the growing season from July through September (Agr. Res. Serv. 1975). Most summer precipitation comes from high intensity convectional thunderstorms (Paulsen and Ares 1962). Annual rainfall is highly variable with drought commonly occurring throughout the desert grasslands. Drought ( $75 \%$ or less of average rainfall) occurs 20 to $40 \%$ of the time (Campbell and Crafts 1939). Potential annual evaporation rate averages $229 \mathrm{~cm}$ (Herbel et al. 1974). The frost-free period lasts approximately 200 days with maximum air temperatures reaching $36^{\circ} \mathrm{C}$ in June.

The growing season generally ranges between 90 and 100 days depending primarily on rainfall distribution. Mean air temperatures range from $16^{\circ} \mathrm{C}$ to $33^{\circ} \mathrm{C}$ during this period with approximately $4 \mathrm{~cm}$ of rain falling per month.

Precipitation during the growing season was $207 \%$ of the mean in $1974,126 \%$ of the mean in 1975 and $72 \%$ of the mean in 1976 (Fig. 1). Production during the 1974 growing season was lush. However, in 1975 over half of the rainfall came at the end of the growing season, losing much of its effectiveness.

The study site was located within a 5.6-ha cattle exclosure at an 


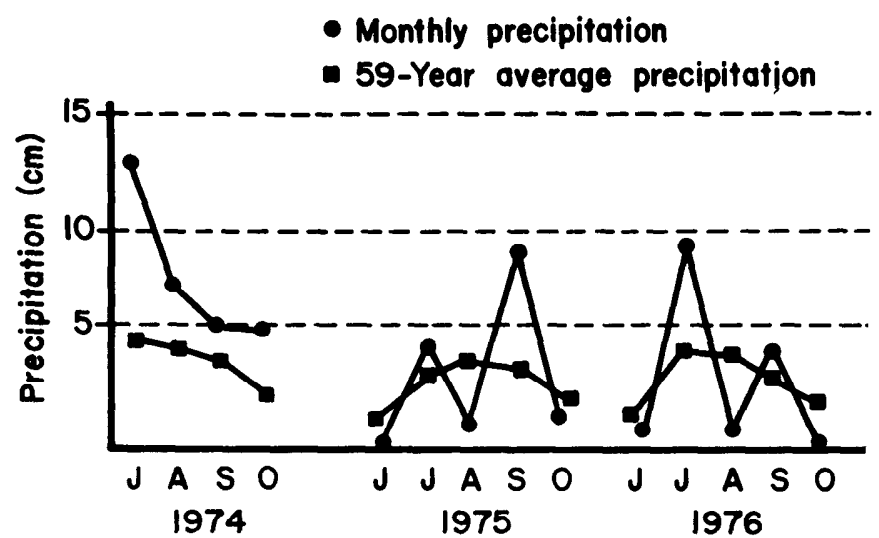

Fig. 1. Monthly precipitation during the growing seasons of 1974,1975 , 1976 and a 59-year average.

elevation of $1,400 \mathrm{~m}$. The site has been protected from cattle grazing since 1965 . Prior to 1960 very little bush muhly was present (Welsh 1972). In 1960 bush muhly began to establish rapidly at the base of individual creosotebush plants. Soils were gravelly sandy loam varying from zero to $92+\mathrm{cm}$ in depth. Soil depth was restricted by a fractured calcium carbonate hardpan. Common subordinate plants are fluffgrass (Erioneuron puchellum), locoweed (Astragalus sp.), broom snakeweed (Xanthocephalum sarothrae), honey mesquite (Prosopis juliflora), and tarbush (Flourensia cernua).

\section{Methods}

The effects of six different clipping treatments were evaluated during 1974, 1975, and 1976. The six treatments involved clipping at different phenological stages during the three-year period. The specific treatments were (1) vegetative, plants clipped only in the vegetative stage once each year during the three-year period; (2) $V F S$, plants clipped once in the vegetative stage in 1974, once during flowering in 1975, and once during leaf senescence in 1976; (3) $V S V$, plants clipped once in the vegetative state in 1974, once in leaf senescence in 1975, and once in the vegetative stage in 1976; (4) maturity, plants clipped once in leaf senescence and once during quiescence in 1974, 1975, and 1976; (5) continuous, plants clipped once in each of the vegetative, flowering, leaf senescence, and quiescence stages during each of the three years; and (6) control, nondefoliated plants. The four phenological stages designating the period of defoliation were the third to fourth leaf stage for vegetative, dough stage for flowering, after seed ripening for leaf senescence, and chlorophyll absent from about $90 \%$ of the leaf tissue for quiescence. Defoliation for all treatments was accomplished by clipping approximately $65 \%$ on a weight basis of the current annual growth.

Phenological data were collected on 24 bush muhly plants per treatment during each defoliation period throughout the study. Phenological measurements were recorded on the same plants during the three-year period.

Six plants were excavated in each treatment during each of the four phenological stages seven days after defoliation, placed on ice in the field and brought into the laboratory, where they were dried at $68^{\circ} \mathrm{C}$ for 48 hours. Total nonstructural carbohydrates were extracted from $0.5 \mathrm{~g}$ root sample in $0.8 \mathrm{~N} \mathrm{H}_{2} \mathrm{SO}_{4}$ (Smith et al.
1964). All samples were refluxed on a crude fiber apparatus. An extension of Forsee's photocolorimetric ferricyanide method was used for determining TNC levels (Morrell 1941).

Elongated internodes were counted on ten randomly selected culms per plant in each treatment prior to defoliation in 1975 and 1976. Eight observations were made per treatment each year.

Clipped material was collected and bagged for each plant during defoliation for dry matter yield determinations. Crown diameters were measured at the end of each growing season for all six treatments on bush muhly.

Analysis of variance, Tukey's $w$-procedure and the pooled- $t$ test were used to analyze data at the $95 \%$ confidence level (Steel and Torrie 1960).

\section{Results and Discussion}

Bush muhly initiated primary leaf growth during mid to late July in all three growing seasons, dependent upon rainfall (Table 1). In late May and early June of 1975 and 1976, limited moisture initiated leaf growth. However, bush muhly returned to a quiescent state in mid-June due to an absence of available soil water. Flowering occurred 34 and 29 days earlier in 1974 than in 1975 and 1976, respectively. This was due to limited rainfall during August in 1975 and 1976 (Fig. 1). Senescence was delayed in 1974 due to available moisture in October and November. In 1976 cold temperatures in September terminated seasonal growth. Soil moisture and air temperature determined the time of quiescence.

Table 1. Dates of phenological stages and range of their occurrence in 1974, 1975, and 1976 for bush muhly.

\begin{tabular}{lcccc}
\hline \hline & \multicolumn{4}{c}{ Dates } \\
\cline { 2 - 4 } Phenology & 1974 & 1975 & 1976 & Range (Days) \\
\hline Vegetative & $7 / 16$ & $7 / 28$ & $7 / 20$ & 12 \\
Flowering & $8 / 14$ & $9 / 17$ & $9 / 12$ & 34 \\
Senescence & $11 / 20$ & $10 / 22$ & $9 / 29$ & 52 \\
Quiescence & $12 / 15$ & $11 / 6$ & $10 / 12$ & 63 \\
\hline
\end{tabular}

Three years of clipping bush muhly did not significantly influence TNC levels until the close of the 1976 growing season. Defoliating bush muhly continuously through the growing season or during maturity significantly reduced TNC levels below that found in nondefoliated plants or plants only clipped during the vegetative stage for three years (Table 2). Prior to the end of the third year, concentration of TNC did not respond to defoliation. VFS and VSV treatments had less effect on TNC levels than did the other four treatments. Although the VFS and VSV treatments included defoliation during maturity, earlier defoliation periods two years in three appeared to nullify this late clipping effect.

Bush muhly elongates the internodes on all culms very early during the vegetative stage. This morphological characteristic allows easy accessibility of apical meristems and axillary buds to grazing. The number of elongated internodes produced per culm was very sensitive to the previous year's clipping treatment (Table 3).

During vegetative growth in 1975 bush muhly plants produced significantly more internodes per culm on nondefoliated plants and plants defoliated during the vegetative stage in 1974 (including the vegetative, VFS and VSV treatments) than plants defoliated continuously or during maturity in 1976 . There was no significant difference in internode numbers per culm in 1975 between plants

Table 2. TNC concentration (\%) of bush muhly roots during quiescence 1976 from plants subjected to different clipping treatments.

\begin{tabular}{|c|c|c|c|c|c|c|}
\hline \multirow[b]{2}{*}{$\begin{array}{l}1974 \\
1975 \\
1976\end{array}$} & \multicolumn{6}{|c|}{ Phenological stage of clipping } \\
\hline & $\begin{array}{l}\text { Control } \\
\text { Control } \\
\text { Control }\end{array}$ & $\begin{array}{l}\text { Vegetative } \\
\text { Vegetative } \\
\text { Vegetative }\end{array}$ & $\begin{array}{l}\text { Vegetative } \\
\text { Flowering } \\
\text { Senescence }\end{array}$ & $\begin{array}{l}\text { Vegetative } \\
\text { Senescence } \\
\text { Vegetative }\end{array}$ & $\begin{array}{l}\text { Maturity } \\
\text { Maturity } \\
\text { Maturity }\end{array}$ & $\begin{array}{l}\text { Continuous } \\
\text { Continuous } \\
\text { Continuous }\end{array}$ \\
\hline$\% \mathrm{TNC}$ & $18.5^{\mathrm{al}}$ & $18.7^{\mathrm{a}}$ & $15.5^{\mathrm{ab}}$ & $16.7^{\mathrm{ab}}$ & $14.5^{b}$ & $14.2^{b}$ \\
\hline
\end{tabular}

'Data followed by a different letter are significantly different at the $95 \%$ level, by Tukeys $w$-procedure. 
Table 3. Mean number of elongated stem internodes on bush muhly prior to defoliation in 1975 and 1976 during the vegetative stage.

\begin{tabular}{lcc}
\hline \hline & \multicolumn{2}{c}{ Number of internodes during vegetative stage } \\
\cline { 2 - 3 } Defoliation treatment & 1975 & 1976 \\
\hline $\begin{array}{l}\text { Control 1974 and 1975 } \\
\text { Vegetative } 1974 \text { and }\end{array}$ & $11.1^{\mathrm{a} 1}$ & $11.8^{\mathrm{a}}$ \\
$\quad \begin{array}{l}1975 \\
\text { Vegetative } 1974\end{array}$ & $9.0^{\mathrm{a}}$ & $9.1^{\mathrm{b}}$ \\
$\begin{array}{l}\text { Flowering } 1975 \\
\text { Vegetative } 1974\end{array}$ & $9.9^{\mathrm{a}}$ & $8.4^{\mathrm{b}}$ \\
$\begin{array}{l}\text { Senescence } 1975 \\
\text { Maturity } 1974 \text { and } 1975\end{array}$ & $10.6^{\mathrm{a}}$ & \\
$\begin{array}{l}\text { Continuous } 1974 \text { and } \\
\text { 1975 }\end{array}$ & $5.1^{\mathrm{b}}$ & $5.4^{\mathrm{c}}$ \\
\end{tabular}

Data in columns followed by a different letter are significantly different at the $95 \%$ level, by Tukey's $w$-procedure.

defoliated in the vegetative stage in 1976 and non-defoliation plants.

Following two years of defoliation all clipped plants showed a decrease in the number of elongated internodes per culm in 1976 regardless of season of defoliation. However, plants defoliated after the flowering stage showed a significantly greater detrimental effect than plants defoliated prior to or during flowering. The data indicate that removing $65 \%$ of the current year's growth in two consecutive years during the vegetative stage is detrimental to the number of elongated internodes produced per culm. However, if defoliation occurs after flowering for only one growing season, the number of elongated internodes produced per culm will be only $50 \%$ of that produced by non-defoliated plants.

Removing $65 \%$ of the leaf area during the vegetative stage accounted for approximately $30 \%$ of the total annual growth in 1974 (Table 4). This was about $50 \%$ less than the amount of forage obtained from the mature or continuous treatments.

In 1975, the second year of clipping, production sharply decreased from that produced in 1974. Although it was impossible to compare the clipping effect across years due to climatic variation, production of four other species studied in the area did not decrease as drastically (Miller 1976). Plants defoliated early in the growing season in 1974 produced significantly more herbage than those clipped continuously or at maturity througout the vegetative flowering and senescence stages in 1975 (Table 4). Clipping during maturity was as detrimental to forage production as continuous defoliation.

In 1976, the third year of defoliation, production appeared to continue to decline. Again climatic variation must be taken into account. Bush muhly clipped in the vegetative stage for two consecutive years produced significantly more forage during this phenological stage than plants subjected to the continuous or VSV treatments during 1976 (Table 4). This response was similar to internode response.

Crown diameter was significantly larger in non-defoliated plants than in defoliated plants during the 1975 growing season (Table 5). Following the 1976 growing season crown diameters in plants continuously defoliated for a three-year period, continued to decrease significantly as compared to non-defoliated plants. The control plants showed no change in size while continuously defoliated plants decreased in diameter by $4 \mathrm{~cm}$.

\section{Conclusions}

The decrease in TNC levels, internode numbers, yield, and crown diameter in 1976 indicated continuous or late defoliation of bush muhly had a greater detrimental impact than any of the remaining clipping treatments. Further, the average number of internodes and plant material harvested during the vegetative stage in 1976 indicated that the seed ripening stage may have been the plants' most vulnerable stage to harvesting. Clipping in the vegetative stage in three consecutive years had the least detrimental effect of the five clipping treatments. Yield and TNC levels were optimal with defoliation practices during vegetative growth. However, removing $65 \%$ of the leaf area on bush muhly during any of the four growth stages reduced plant vigor as observed by yield and number of internodes present. Only the continuous and maturity defoliations resulted in a significant decrease in TNC levels. The vegetative treatment may have had less impact on the plants since only $30 \%$ of the total season's growth was harvested. The decrease in production from 1974 through 1976 on the five clipping treatments appeared to be caused by more than climate alone. The reduction in both crown diameters and elongated internodes due to clipping suggested defoliation to be part of the cause for the sharp decrcase

Table 4. Mean dry weight of forage harvested per bush muhly plant from five defoliation treatments during 1974,1975 and 1976. Data are accumulative within years across phenology.

\begin{tabular}{|c|c|c|c|c|c|c|c|c|c|c|c|c|}
\hline \multirow[b]{3}{*}{ Treatment } & \multicolumn{12}{|c|}{ Phenological stage at time of clipping } \\
\hline & \multicolumn{4}{|c|}{1974} & \multicolumn{4}{|c|}{1975} & \multicolumn{3}{|c|}{1976} & \multirow[b]{2}{*}{ Qui } \\
\hline & Veg 1 & Flow & Sen & Qui & Veg & Flow & Sen & Qui & $\mathrm{Veg}$ & Flow & Sen & \\
\hline $\begin{array}{l}\text { Vegetative } \\
\text { VFS }\end{array}$ & $34.5^{\mathrm{aiz}}$ & & & & $11.9^{\mathrm{a}}$ & & & & $4.5^{\mathrm{a}}$ & & & \\
\hline $\begin{array}{l}\text { VFS } \\
\text { VSY }\end{array}$ & $34.8^{\mathrm{a}}$ & & & & & $12.3^{\mathrm{a}}$ & & & & & $2.3^{\mathrm{a}}$ & \\
\hline VSV & $46.8^{\mathrm{a}}$ & & & & & & $20.7^{\mathrm{a}}$ & & $0.9^{\mathrm{b}}$ & & & \\
\hline Maturity & & & $60.4^{a}$ & $72.9^{\mathrm{a}}$ & & & $5.7^{\mathrm{b}}$ & $7.1^{\mathrm{a}}$ & & & $0.5^{b}$ & $0.5^{\mathrm{b}}$ \\
\hline Continuous & $36.1^{\mathrm{a}}$ & 45.3 & $55.1^{\mathrm{a}}$ & $60.3^{\mathrm{a}}$ & $1.1^{\mathrm{b}}$ & $2.3^{\mathrm{b}}$ & $7.2^{\mathrm{b}}$ & $9.4^{\mathrm{a}}$ & $0.6^{\mathrm{b}}$ & 0.7 & $2.0^{\mathrm{a}}$ & $2.0^{\mathrm{a}}$ \\
\hline
\end{tabular}

'Abbreviations are: Veg = Vegetative, Flow = Flowering, Sen = Senescence, Qui = Quiescence. These treatments reflect the period of defoliation for 1974,1975 and 1976 respectively.

${ }^{2}$ Data in columns followed by a different letter are significantly different at the $95 \%$ level by Tukey's $w$-procedure.

Table 5. Mean annual change in crown diameter (cm) per bush muhly plant during the 1975 and 1976 growing seasons.

\begin{tabular}{lclcccc}
\hline \hline \multicolumn{1}{c}{ Phenological stage at time of clipping } \\
\hline 1974 & Control & Vegetative & Vegetative & Vegetative & Maturity & Continuous \\
1975 & Control & Vegetative & Flowering & Senescence & Maturity & Continuous \\
1976 & Control & Vegetative & Senescence & Vegetative & Maturity & Continuous \\
\hline 1975 & $6.4^{\mathrm{a}}$ & $2.0^{\mathrm{b}}$ & $1.0^{\mathrm{b}}$ & $-0.5^{\mathrm{b}}$ & $-0.7^{\mathrm{b}}$ & $-2.0^{\mathrm{b}}$ \\
1976 & $0.0^{\mathrm{a}}$ & $-0.5^{\mathrm{ab}}$ & $-2.3^{\mathrm{ab}}$ & $-1.6^{\mathrm{ab}}$ & $-0.7^{\mathrm{bb}}$ & $-4.0^{\mathrm{b}}$ \\
\hline
\end{tabular}

Data in rows followed by different letters are significantly different at the $95 \%$ level by Tukey's $w$-procedure. 
in production.

Past authors probably attributed the decrease of bush muhly throughout its range to high palatibility. However, it was observed in this study and others (Welsh and Beck 1976) that livestock did not graze bush muhly until late in the growing season and during quiescence. This was due to a decrease in the availability of more desirable forages. The extensive decrease in bush muhly is more likely a result of its low resistance to grazing. The morphological characteristics of this plant do not appear to be well adapted for grazing. Elevated apical meristems and axillary buds make the growing points accessible to removal. As a result of the high proportion of elevated meristematic tissue, it is likely that a considerable amount of food reserves are stored in the culms well above the crown. Unlike most other grasses that tiller from nonelongated internodes near the crown, culms on bush muhly commonly branch, forming new culms well above the ground. It was also observed that the culms were easily broken off at the crown by grazing animals, which would be more damaging than the defoliation treatments described. In a study on the effects of defoliation on four common range grasses in the Southwest, it was concluded that bush muhly was the least resistant to grazing (Miller 1976).

To maintain stands of bush muhly, utilization must be below $65 \%$, especially if grazing is occurring after flowering. This species is not a highly desirable plant to manage for livestock feed due both to its low palatability and its low resistance to grazing. However, in many deteriorated ranges invaded by creosotebush it may be our best alternative.

\section{Literature Cited}

Agricultural Research Service. 1975. File data. U.S. Dep. Agr., Las Cruces, N.M.

Campbell, R.S., and E.C. Crafts. 1939. How to keep and increase black grama on southwestern ranges. U.S. Dep. Agr. Leaflet. 180. 8 p.

Gardner, J.L. 1951. Vegetation of the creosotebush area of the Rio Grande Valley in New Mexico. Ecol. Monogr. 21: 379-403.

Gould, F.W. 1951. Grasses of southwestern United States. Univ. of Arizona Press, Tucson. 347 p.

Herbel, C.H., R. Steger, and W.L. Gould 1974. Managing semidesert ranges of the Southwest. New Mexico State Univ. Coop. Ext. Serv. Cir. 456. $48 \mathrm{p}$.

Miller, R.F. 1976. Response of five southwestern range plants to season of defoliation. Ph.D. Thesis. New Mexico State Univ., Las Cruces. $104 \mathrm{p}$.

Morrell, S.A. 1941. Rapid determination of reducing sugars. Inc. Eng. Chem. (Anal. Ed.). 13: 249-251.

Paulsen, H.A., and F.N. Ares. 1962. Grazing values and management of black grama and tobosa grasslands and associated shrub ranges of the Southwest. U.S. Dep. Agr. Tech. Bull. 1270. 56 p.

Smith, D., G.M. Paulsen, and H.A. Raguse. 1964. Extraction of total available carbohydrates from grass and legume tissue. Plant Physiol. 39: 960-962.

Steel, R.G.D., and J.H. Torrie. 1960. Principles and procedures of statistics. McGraw-Hill Book Co. Inc., New York. 481 p.

Welsh, R.G. 1972. Some ecological relationships between creosote (Larrea tridentata D.C.) and bush muhly (Muhlenbergia porteri Scribn). M.S. Thesis. New Mexico State Univ., Las Cruces. 36 p.

Welsh, R.G., and R.F. Beck. 1976. Some ecological relationships between creosotebush and bush muhly. J. Range Manage. 29: 472-475. 